DOI: $10.15290 /$ bsp.2020.25.04.16

Received: 03.08.2020

Accepted: 04.09.2020

\title{
Aušrinė Pasvenskienė
}

Vytautas Magnus University, Lithuania

ausrine.pasvenskiene@vdu.lt

ORCID: https://orcid.org/0000-0003-3503-414X

\section{Milda Žaliauskaitè}

Vytautas Magnus University, Lithuania

milda.zaliauskaite@vdu.lt

ORCID: https://orcid.org/00000-0002-8603-7538

\section{The Right to Education for Learners with Special Educational Needs in Lithuanian Higher Education}

\begin{abstract}
This article considers the implementation of the right to higher education for learners with special needs in Lithuania. Although this right is guaranteed by various international documents and national legal acts, the main responsibility to ensure equality in higher education for all learners is embedded in the discretion of higher education institutions. The aim of this article is to analyse Lithuanian legal regulation regarding inclusion of students with special needs into higher education institutions and to evaluate Lithuanian university policies, as institutional documents, concerning students with special educational needs. A brief overview and comparison of all Lithuanian HEI policies illustrates the institutional approach towards educating students with SEN and the level of attentiveness to realization of their right to education. The research also considers pivotal challenges of ensuring inclusive education for those students as well as presents recommendations to address these challenges. Keywords: Inclusion, higher education, special educational needs, right to education.
\end{abstract}

\section{Introduction}

The right to education, as one of the fundamental human rights, also covers access to higher education. Although the right to education is guaranteed for learners with special educational needs (SEN), accessing higher education and adapting to the process of teaching and learning remains an ongoing struggle for SEN-learners. 
Inclusion in HEIs is a topic of significance with far-reaching implications; however, it remains obscure, lacking conceptual clarity and focus, despite receiving considerable attention ${ }^{1}$. One of the reasons why the enjoyment of higher education might be considered as more restricted for learners with SEN is the lack of information, the unpreparedness of administrative and academic personnel and the general lack of appropriate tools to manage various aspects of the study process of SEN-learners. Various international and national laws, such as Standard Rules on the Equalization of Opportunities for Persons with Disabilities, Convention on the Rights of Persons with Disabilities, National Education Strategy 2013-2020, Law on Higher Education and Research, etc. (more discussed in section 2 and 3)aim to prevent discrimination and to ensure the right to education for everyone. However, whether in practice they are sufficient enough to ensure inclusive higher education for students with SEN remains a question of debate.

The aim of this article, therefore, is to analyse Lithuanian legal regulation regarding inclusion of students with SEN into higher education institutions (HEIs) ${ }^{2}$. Furthermore, as universities are those entrusted with the adaptation of the study process and study programmes to learners with SEN, and autonomous institutions at the same time, a brief overview and comparison of all Lithuanian HEI policies are presented in order to illustrate the institutional approach towards educating students with SEN. This type of analysis is considered essential as universities play a crucial role in guaranteeing equal rights to all students and as it also demonstrates the level of attentiveness to the realization of the right to education of students with SEN. Institutional analysis includes all information, policies and/or documents addressing the matter of students with SEN. It is presumed that in order to ensure effective and timely access of such information, it must be available to students online, as the opposite situation would be considered as an impediment of students' rights. It has been argued that access to education has many faces, including physical and communications access which facilitates the increased integration of students with SEN ${ }^{3}$. For this reason, all information, policies and/or documents that are accessible on universities' websites were considered. It must also be noted that this article is not designed to exhaustively analyse and compare provisions of various international and national legal acts. The focus is set on unfolding the overall context of legal regulation that forms the core of inclusive education for students with SEN,

1 A. Collins, F. Azmat, and R. Rentschler, 'Bringing Everyone on the Same Journey': Revisiting Inclusion in Higher Education, „Studies in Higher Education 44” 2018, no. 8, p. 1475-87, https:// doi.org/10.1080/03075079.2018.1450852.

2 In Lithuania there are two types of higher education institutions: universities and colleges. This article focuses only on universities and terms 'higher education institution (HEI)' and 'university' will be used as synonims.

3 J.A. Simon, Legal Issues in Serving Students with Disabilities in Postsecondary Education, „New Directions for Student Services" 2011, no. 13, p. 95-107, https://doi.org/10.1002/ss. 397. 
therefore, the principal and the most prominent legal acts are reviewed. Finally, pivotal challenges to ensure inclusive education for SEN students and policy and practical recommendations are considered.

Methods that were used throughout this article include international and national legal documents analysis and qualitative analysis of Lithuanian HEI policies regarding the matter of students with SEN. The data gathered were analysed using comparative, conceptual, descriptive, systematic and logical techniques, some of the results were also visualised in the column chart. This approach enabled the implementation of the research following the aim of the article and to formulate clear and valuable results. The structure of this article is designed according to the logical line and interdependency of the topics that are set out into four sections: firstly, the context of international and EU regulation is reviewed; secondly, national regulation regarding SEN-learners is revised; third section includes descriptive and comparative analysis of Lithuanian HEI institutional approach towards students with SEN; finally, principal challenges and respective recommendations are presented.

\section{The Context of International and EU Regulation}

There are several international documents recognizing the right to education. In this section we discuss only the most fundamental instruments with relevance for our analysis and the topic. The Universal Declaration of Human Rights(UDHR) (1948) is the primary document determining the right to education as a fundamental human right. Later documents develop and broaden this concept, yet the Declaration still remains the basis for all subsequent treaties, regulations and other international and national laws. Article 26 establishes the general right to education but also makes a distinction as to the substance of this right between three types of education: elementary and fundamental education, technical and professional education and higher education. ${ }^{4}$ Whereas elementary and fundamental education should be free and compulsory, technical and professional education should be generally available, "... higher education shall be equally accessible to all on the basis of merit." The UNESCO Convention against Discrimination in Education (CDE) echoes this formulation of the right to eductaion in relation to higher education by stating that signatory parties undertake "to make higher education equally accessible to all on the basis of individual capacity" 6 . The International Covenant on Economic, Social and Cultural Rights (ICESCR) goes further by declaring that "[h]igher education shall be made equally accessible to all, on the basis of capacity, by every appropriate means,

4 Article 26, Universal Declaration of Human Rights, United Nations (1948).

5 Article 26, Ibidem.

6 Article 4, Records of the General Conference, 11th Session, Resolutions, United Nations Educational Scientific and Cultural Organization (1960). 
and in particular by the progressive introduction of free education"7. The General Comments on this provision note that the prohibition against discrimination "applies fully and immediately to all aspects of education and encompasses all internationally

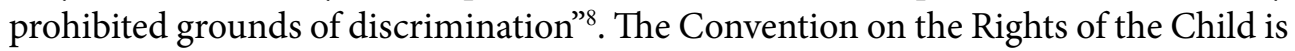
less specific when it streesses that states should" [m]ake higher education accessible to all on the basis of capacity by every appropriate means".

In particular in relation to persons with special needs and their right to education, states that are parties to the CDE (1960) undertook to formulate, develop and apply their national policies for education in a way "to promote equality of opportunity and of treatment"10. This document, as well as the UDHR and the ICESCR, also reiterates that education is supposed to "be directed to the full development of the human personality and to the strengthening of respect for human rights and fundamental freedoms." 11 The European Convention on Human Rights (ECHR)stresses that no person shall be denied the right to education ${ }^{12}$. It also underlines the importance of securing human rights and freedoms from discrimination on any ground, such as to race, colour, sex, language, religion, political or other opinion, national or social origin, property, birth or other status ${ }^{13}$.

With the exception of the Convention on the Rights of Persons with Disabilities (CPD), none of the documents discussed considers the right to education in the context of people with special educational needs, especially people seeking to acquire higher education. Article 24 of the convention recognizes the right to education for persons with disabilities without discrimination and on an equal basis with others. Although higher education is not explicitly mentioned, it is, however, stressed that signatory states undertake to ensure an inclusive education system at all levels, adult education and life-long learning. This document can be considered as more progressive and effective compared to earlier documents for the simple reason that it does include several practical recommendations. One of the most significant

Article 13, International Covenant on Economic, Social and Cultural Rights, General Assembly United Nations (1976).

8 Article 13, CESCR General Comment No 13: The Right to Education, Office of the High Commisioner for Human Rights (1999), http://www.refworld.org/docid/4538838c22.html (08.07.2020).

9 Article 28, Convention on the Rights of the Child, General Assembly United Nations (1989).

10 Article 6, Records of the General Conference, 11th Session, Resolutions, United Nations Educational Scientific and Cultural Organization (1960).

11 Article 5, Ibidem; Article 26, Universal Declaration of Human Rights, United Nations (1948); Article 13, International Covenant on Economic, Social and Cultural Rights, General Assembly United Nations (1976).

12 Article 2, European Convention on Human Rights, As amended by Protocols Nos. 11 and 14, supplemented by Protocols Nos. 1, 4, 6, 7, 12, 13 and $16 \$$, European Court of Human Rights (1950).

13 Article 2, Ibidem. 
suggestions is “... to employ teachers, including teachers with disabilities, who are qualified in sign language and/or Braille, and to train professionals and staff who work at all levels of education. Such training shall incorporate disability awareness and the use of appropriate augmentative and alternative modes, means and formats of communication, educational techniques and materials to support persons with disabilities." ${ }^{14}$ This provision is particularly important for promoting understanding that an effective guarantee of the right to education for people with SEN necessitates appropriate training for teaching and supporting personnel. Nevertheless, this convention is still rather general and declarative, and serves more as a general inspiration for national legislators. It is also worth to mention Standard Rules on the Equalization of Opportunities for Persons with Disabilities (1993) that also promotes inclusive education, yet one of the distinct approaches it suggests is to include “... persons with disabilities and their families and organizations to participate in public education programmes concerning disability matters" 15 .

Although there are no legally binding documents at EU level concerning education, national efforts towards inclusive education are greatly supported and complemented through various EU documents and mechanisms. The Joint Report of the Council and the Commission on the Implementation of the Strategic Framework for European Cooperation in Education and Training (ET2020) suggested inclusive education, equality, equity, non-discrimination and the promotion of civic competences as one of the priority areas ${ }^{16}$. The concrete issues of this area included enhancing access to quality and inclusive education and training for all learners, including learners with special needs ${ }^{17}$. EU documents clearly express the need to ensure availability and accessibility of education to "all learners of all ages, including those facing challenges, such as those with special needs or who have a disability, those originating from disadvantaged socioeconomic backgrounds, migrant backgrounds or geographically depressed areas or war-torn zones, regardless of sex, racial or ethnic origin, religion or belief, disability, age or sexual orientation"18.

14 Convention on the Rights of Persons with Disabilities (CRPD), United Nations (2006).

15 Standard Rules on the Equalization of Opportunities for Persons with Disabilities A/RES/48/9

$\$$, General Assembly United Nations (1993), https://www.independentliving.org/standardrules/ StandardRules.pdf (08.07.2020).

16 Joint Report of the Council and the Commission on the Implementation of the Strategic Framework for European Cooperation in Education and Training (ET 2020) 2015/C 417 \$, European Commission and European Council (2015), http://www.refworld.org/ docid/4538838c22.html (08.07.2020).

17 Ibidem.

18 Conclusions of the Council and of the Representatives of the Governments of the Member States, Meeting within the Council, on Inclusion in Diversity to Achieve a High Quality Education For All 2017/C 62/, Council of the European Union (2017): https://op.europa.eu/en/publicationdetail/-/publication/f16edd4b-fae8-11e6-8a35-01aa75ed71a1 (08.07.2020). 
It is evident that the right of persons to have access to an education without discrimination or exclusion is promoted internationally. However, despite the attempts of the CPD to propose more specific recommendations, all other international documents are merely declarative, conceptual and fail to provide more specific guidance how to ensure the proper implementation of the right to education. More importantly, although the specific needs of persons with SEN may be implicitly anticipated, other international instruments fail to acknowledge the special needs of SEN-learners. On the other hand, it is up to the states to develop specific and more thorough national laws and education strategies to fill in the gaps unregulated by international treaties and laws.

\section{National Regulation for the Education of Learners with SEN}

After re-gaining its independence in 1991, Lithuania introduced major reforms following the principles of humanism and justice. It started implementing the rights of the disabled as guaranteed in international documents and recognized that integration of the disabled into social and public life is essential for a democratic and civilized country. In 1991, the new Law on Education initiated the process of educational reform by determining the structure of the Lithuanian education system and established the foundations of the activities and governance of educational institutions (except for HEIs). In 1992, the General Concept of Education established four fundamental principles of Lithuanian education: humanism, democracy, nationalism and renewal ${ }^{19}$. The Soviet education system provided that all children with special educational needs should be educated in separate schools; renouncing this approach made children with disabilities 'educable'. The provisions/principles of the General Concept of Education served as the basis developing the Special Education Framework, the fundamental principle of which advocated for the integration of the disabled into mainstream educational institutions $s^{20}$. Two forms of integration were introduced - full, when a child is educated in a class or group setting of a mainstream general education institution, and partial, when a group of persons with special needs is formed in a mainstream class of a general education institution. Simultaneously, special schools for children with severe specific disabilities (vision, hearing, movement, etc.) have been operating ${ }^{21}$.Special education has become a part of the education system of Lithuania and includes early and pre-

19 General Concept of Education in Lithuania, The Ministry of Culture and Science of the Republic of Lithuania (1992), https://www.smm.lt/uploads/documents/General_concept_of_education_ in_Lithuania_1992.pdf (08.07.2020).

20 Ibidem.

21 Nacionalinis Švietimo Plètotès Raportas, LR švietimo ir mokslo ministerija (2001), https://www. smm.lt/uploads/lawacts/docs/687_f36e428baa3belaf5722f6d880e03896.pdf (04.12.2020). 
-school education, general training, vocational, college and university education, adult education and supplementary education ${ }^{22}$. Today, learners with different types of SEN attend educational institutions at the entire variety of levels of compulsory and non-compulsory education. Nevertheless, access to education in Lithuania for learners with SEN is regulated differently at various levels of education. Therefore, the main question that is being raised in this article is whether the current regulation in Lithuania guarantees quality education for the students with SEN.

Provisions of the former Law on Special Education provided more detailed information and instructions for early, pre-school and general education and training of persons with special needs. Yet, higher education did not receive much attention. The law indicated that persons with special needs may acquire a profession at a HEI and established certain rights regarding admission procedures. Besides general conditions of equal admission, learners had a right to be admitted on the basis of precedence. HEIs were also given a right to establish additional privilege conditions and procedures of admission for students with special needs. HEIs had autonomy not only to adapt procedures for entrance examinations but also procedures for organising intermediate, qualifying and state examinations for students with special needs upon individual request ${ }^{23}$. The Law on Special Education was repealed in 2011 by the Law on Education. The latter became the main law addressing the relevant issues regarding education of learners with SEN.

One of the main objectives of the National Education Strategy 2013-2020 is to ensure access to education and equal opportunities. The strategy emphasises the need to provide the most favourable opportunities to develop individual abilities and meet special education and study needs for pupils, students and young people. Moreover, it underlines the necessity to provide effective pedagogical and psychological support for students with learning difficulties ${ }^{24}$. The Law on Education establishes the goals, principles and foundations of the structure of the entire educational system; however, its provisions are mainly oriented towards compulsory education. The foundations of activities of HEIs are set out by the Law on Higher Education and Research ${ }^{25}$, yet it does not provide any regulation on special education. The concept of SEN is established in the Law on Education which describes it as the "need for assistance and services in the course of the training process, arising

22 Article 9, Law on Education of the Republic of Lithuania I-1498 \$, The Parliament of the Republic of Lithuania (1991), https://e-seimas.lrs.lt/portal/legalAct/lt/TAD/df672e20b93311e5be9bf78e07ed 6470?jfwid=rivwzvpvg (08.07.2020).

23 Article 21, Ibidem.

24 The National Strategy for Education 2013-2022, The Parliament of the Republic of Lithuania (2013), https://e-seimas.lrs.lt/portal/legalAct/lt/TAD/TAIS.463390 (08.07.2020).

25 Republic of Lithuania Law on Higher Education and Research XI-242 \$, The Parliament of the Republic of Lithuania (2009), https://e-seimas.lrs.lt/portal/legalAct/lt/TAD/548a2a30ead611 e59b76f36d7fa634f8?jfwid=rp9xf47k7 (08.07.2020). 
from a person's exceptional capabilities, congenital or acquired disorders, adverse environmental factors" ${ }^{26}$. This description allows to distinguish three main categories that SEN covers: 1) exceptional capabilities; 2) congenital or acquired disorders and 3) adverse environmental factors ${ }^{27}$. However, all regulation on SEN focuses only on the latter two. So far, the Law on Education is the only legal act which mentions a person's exceptional capabilities as one of the elements of SEN. What is more, as further research of institutional policies will demonstrate, the concepts of congenital or acquired disorders and adverse environmental factors are also not commonly used. Analysed national regulation also does not reflect consistency in used terminology ${ }^{28}$. For example, in the description of SEN and division procedure of SEN the learners with SEN are divided into three groups: learners with disabilities, learners having disorders and learners having learning difficulties ${ }^{29}$. This establishes the procedure for determining groups of learners with SEN and the criteria for categorising them into levels. Nevertheless, this regulation applies only for children and young people until the age of 21 in a mainstream education, covering only pupils and leaves much uncertainty for the students of HEIs ${ }^{30}$. The Law on Education states that when necessary study programmes shall be adapted to learners with SEN in accordance with the procedure established by a respective $\mathrm{HEI}^{31}$. Although such autonomy of HEIs allows them to prepare their internal policies in a more flexible and effective manner, the analysis of existing universities' policies on students with SEN reveal a number of problems. Thus, establishing certain guidelines or recommendations for HEIs could help to ensure the right to education for students with SEN and ensure successful inclusion.

Article 2 (26), Law on Education of the Republic of Lithuania I-1498 \$, The Parliament of the Republic of Lithuania (1991), https://e-seimas.lrs.lt/portal/legalAct/lt/TAD/df672e20b93311 e5be9bf78e07ed6470?jfwid=rivwzvpvg (08.07.2020).

Ibidem.

28 Research shows that terminology is important in communications to provide information about support to students or encourage disclosure of information about conditions, as if students do not identify with the terminology used it creates obstacles to accessing support. See more at: K. Lister, T. Coughlan, and N. Owen, ,Disability' or 'Additional Study Needs'? Identifying Students' Language Preferences in Disability-Related Communications, „European Journal of Special Needs Education" 2020, no. 5, https://doi.org/10.1080/08856257.2020.1743409.

29 Description of the Determination of Groups of the Pupils with Special Educational Needs and Procedure of the Division of the Educational Needs into the Levels V-1265/V-6 \$, Minister for Education and Science and Minister for Social Security and Labour and Minister for Health (2011), https://e-seimas.lrs.lt/portal/legalAct/lt/TAD/TAIS.404013 (08.07.2020).

$30 \quad$ Ibidem.

31 Article 2 (26), Law on Education of the Republic of Lithuania I-1498 \$, The Parliament of the Republic of Lithuania (1991), https:/e-seimas.lrs.lt/portal/legalAct/lt/TAD/ df672e20b93311e5be9bf78e07ed6470?jfwid=rivwzvpvg (08.07.2020). 


\section{Institutional Approach Towards the Students with SEN}

To evaluate whether and to what extent Lithuanian universities cater for SEN we looked for all types of information and/or documents, policies (further in the text are called - policies, in a broader sense) concerning studies of students with SEN, that were available on the websites of all $17^{32}$ Lithuanian state and private universities. The policies were analysed according to the following criteria: terminology; adjustments of the study process and examination; physical accessibility of the buildings and premises; financial support; psychological counselling; providing information and raising awareness in the university's community; procedure (Table 1$)^{33}$. Out of the 17 universities surveyed, websites of only 13 include certain information and/or policies on teaching and learning of students with SEN. The information provided varies depending on the areas they cover, their extent and comprehensiveness. Only a few policies are detailed and provide the necessary information for SEN-students, which reflects universities' mission to create an environment where SEN-students can study without barriers. For example, as a long-term commitment to systematic work on equal opportunities for people with disabilities, a strategy of an Open University for People with Disabilities was first approved in $2017^{34}$. Nevertheless, the majority of the policies provide limited information or concentrate only on certain areas, for example financial support.

3212 universities out of 17 are public universities; 4 universities are private; one university is the branch of the University of Bialystok (Poland). As the Law on Higher Education and Research applies to all Lithuanian universities and significant differencies in the policies of public and non-public universities were not identified, the research was performed without distinction between public and non-public universities.

33 Terminology was checked in order to see what type of terminology is used, whether it is in compliance with national regulation and what it entails. Adjustments of the study process and examination entails information about the types of adjustments that are offered for the students with SEN. Physical accessibility of the buildings and premises entails information in regard to whether and how detailed information universities provide about the accessibility of their buildings and premises. Financial support - information about the types of scholarships and other financial support provided for the students with SEN. Psychological counselling information in regard to whether it includes special provisions about the special services to the students with SEN. Community's involvement - information in regard to whether and how academic community is involved in making decisions and adjustments of the study process, how information about the students with SEN is provided and awareness of the university's community is raised. Procedure - whether and how detailed information is provided in regard to the procedure of applying for the adjustments, who makes a decision and according to what criteria, what documents or evidence about the SEN are needed.

34 Open University for People with Disabilities, Vilnius University (2020), https://www.vu.lt/en/ about-vu/university-life/open-university-for-people-with-disabilities (08.07.2020). 
Table 1. The policies concerning the studies of the students with SEN in Lithuanian universities.

\begin{tabular}{|c|c|c|c|c|c|c|c|}
\hline $\begin{array}{l}\text { University's } \\
\text { Code }\end{array}$ & Terminology & $\begin{array}{l}\text { Adjustments } \\
\text { of the study } \\
\text { process and } \\
\text { examination }\end{array}$ & $\begin{array}{c}\text { Physical } \\
\text { accessibility }\end{array}$ & $\begin{array}{l}\text { Financial } \\
\text { support }\end{array}$ & $\begin{array}{l}\text { Psychological } \\
\text { counselling }\end{array}$ & $\begin{array}{l}\text { Community's } \\
\text { involvement }\end{array}$ & Procedure \\
\hline U1 & $\begin{array}{c}\text { Students with } \\
\text { disability }\end{array}$ & + & + & + & + & - & - \\
\hline U2 & $\begin{array}{l}\text { Students with } \\
\text { disability/ } \\
\text { Students with } \\
\text { SEN }\end{array}$ & + & + & + & + & + & + \\
\hline U3 & $\begin{array}{c}\text { Students with } \\
\text { SEN }\end{array}$ & - & + & + & + & - & - \\
\hline U4 & $\begin{array}{l}\text { Students with } \\
\text { disability }\end{array}$ & - & + & + & + & + & - \\
\hline U5 & $\begin{array}{c}\text { Students with } \\
\text { disability }\end{array}$ & - & - & + & + & - & - \\
\hline U6 & $\begin{array}{c}\text { Students with } \\
\text { disability }\end{array}$ & - & - & + & + & - & - \\
\hline U7 & $\begin{array}{l}\text { Students with } \\
\text { disability }\end{array}$ & - & - & + & + & - & - \\
\hline U8 & $\begin{array}{c}\text { Students with } \\
\text { disability }\end{array}$ & - & - & + & + & - & - \\
\hline U9 & $\begin{array}{c}\text { Students with } \\
\text { disability }\end{array}$ & - & - & + & + & - & - \\
\hline U10 & $\begin{array}{c}\text { Students with } \\
\text { disability }\end{array}$ & + & + & + & + & - & - \\
\hline U11 & - & - & - & - & - & - & . \\
\hline U12 & $\begin{array}{c}\text { Students with } \\
\text { disability }\end{array}$ & - & + & + & + & - & - \\
\hline U13 & $\begin{array}{c}\text { Students with } \\
\text { disability }\end{array}$ & - & - & + & + & - & - \\
\hline U14 & - & - & - & - & - & - & . \\
\hline U15 & $\begin{array}{c}\text { Students with } \\
\text { SEN }\end{array}$ & - & - & - & - & - & - \\
\hline U16 & $\begin{array}{l}\text { Students with } \\
\text { disability }\end{array}$ & - & - & - & - & - & - \\
\hline U17 & $\begin{array}{l}\text { Students with } \\
\text { SEN }\end{array}$ & - & - & + & - & - & - \\
\hline
\end{tabular}

With regards to the terminology, the majority of policies use the term 'students with disabilities' ${ }^{35}$. Only two universities use the term 'students with SEN', however, their more detailed descriptions demonstrate that the term covers only physical disability or discusses only financial support for the disabled students. Only one policy specifies that the term 'students with disabilities', also includes non-physical learning disabilities, mental health or autism caused difficulties ${ }^{36}$. The same university in its description for individualizing the study process for the SEN-students uses

35 Research demonstrates that terms like 'disability' and 'disabled' are often unpopular with students, 'disability' and 'disabled', however, these are the most common preference when providing specific information about a condition. See more at: K. Lister, T. Coughlan, and N. Owen, ,Disability' or 'Additional Study Needs'? Identifying Students' Language Preferences in Disability-Related Communications, „European Journal of Special Needs Education” 2020, no. 5, https://doi.org/10. 1080/08856257.2020.1743409.

36 Open University for People with Disabilities, Vilnius University (2020), https://www.vu.lt/en/ about-vu/university-life/open-university-for-people-with-disabilities (08.07.2020). 
the term 'individual needs caused by disability ${ }^{37}$. This leads to uncertainty whether this document also applies when students have difficulties caused by adverse environmental factors. In all other cases it can be presumed that the policies mainly refer to congenital or acquired disorders. This suggests that the statutory term 'students with SEN' is not yet recognized and widely applied, especially considering that the term distinguishes three categories of $\mathrm{SEN}^{38}$. Accordingly, universities should adopt the term 'students with SEN' with it statutory scope and provide in their policies possibilities of adjustments for both, students with congenital or acquired disorders and students having difficulties caused by adverse environmental factors.

Commonly universities have a separate section on their websites on studies and students with disabilities ${ }^{39}$. Less than a half of universities provide, often only very limited, information about the physical accessibility of buildings. It is often stressed that although not all university buildings and premises are accessible for people with limited mobility, efforts are made to improve, reconstruct and adjust physical accessibility. Five universities ${ }^{40}$ provide more detailed information about the adaptability of university premises to students with disability. They provide a list of buildings and premises which are fully, partly or not adapted to the needs of disabled students, including disability access maps of university buildings ${ }^{41}$. Moreover, detailed descriptions of university premises and facilities also include information about special recreation rooms, workplaces designed for students with disabilities, accommodation in dormitories, adapted elevators, doors, entrances to the classroom ${ }^{42}$ or even a specially adapted room which provides diabetics a safe environment to take necessary medication and drugs ${ }^{43}$.

Merely three policies cover adjustments of the study process and examinations. Adjustments depending on student's individual needs may include accessible font style

37 Procedure on the Study Individualization for the Individual Needs of Disability, Vilnius University (2019), https://www.vu.lt/site_files/Studiju_individualizavimo_pagal_individualiuosius_poreikius_ kylancius_dèl_negalios_tvarkos_aprasas.pdf(08.07.2020).

38 Article 2 (26), Law on Education of the Republic of Lithuania I-1498 §, The Parliament of the Republic of Lithuania (1991), https://e-seimas.lrs.lt/portal/legalAct/lt/TAD/df672e20b93311 e5be9bf78e07ed6470?jfwid=rivwzvpvg (04.12.2020).

39 For example, https://www.vu.lt/en/about-vu/university-life/open-university-for-people-withdisabilities; https://www.vdu.lt/en/studies/why-vmu/a-disabled-friendly-university/; https:// www.mruni.eu/en/university/asm_spec_poreikiais/paslaugos/ (08.10.2020).

$40 \quad$ Marked in grey, Table 1.

41 VMU Map, Vytautas Magnus University (2020), https://www.vdu.lt/en/contacts/vmu-map/.

42 Disability-Friendly University, Vytautas Magnus University (2020), https://www.vdu.lt/en/studies/ why-vmu/a-disabled-friendly-university/(04.12.2020);OpenUniversityforPeoplewithDisabilities, Vilnius University (2020), https://www.vu.lt/en/about-vu/university-life/open-university -for-people-with-disabilities (08.10.2020).

43 Disability Resources, Services, Mykolas Romeris University (2020), https://www.mruni.eu/en/ university/asm_spec_poreikiais/paslaugos/ (08.10.2020). 
and size, use of assistive technology and software for studying ${ }^{44}$, distance learning ${ }^{45}$. Students with hearing difficulties may get help of a sign language interpreter or special tools to improve hearing ${ }^{46}$. For examinations, students can be provided with flexible conditions making alternative examination arrangements, using various assistive technology and software and giving additional time $\mathrm{e}^{47}$, alternative examination forms $\mathrm{s}^{48}$, and flexible exam schedules ${ }^{49}$. Only one policy establishes a detailed procedure and the types of individualized study process, according to the type of disability ${ }^{50}$. It provides a list of the adjustments that can be made in case of physical disability, for example, infrastructural adjustments, flexible studying schedule, additional time for examination from $25-100$ per cent, additional breaks during the class or exam, alternative forms of assessments, distance examination, technological tools and etc. Similar adjustments are provided in cases of visual impairment, blindness and hearing impairment. In case of psychosocial disability (autism and mental disorders) students may also be given the possibility to take exams in a separate room or a familiar environment. Moreover, adjustments can be made in case of learning difficulties (dyslexia, dysgraphia, dyscalculia, etc.) and somatic diseases (diabetes, multiple sclerosis). Such detailed description was approved by the university in 2019 and to date it is the only example of such detailed institutional document in regard to SEN-students. Although this particular policy constitutes a good-practice example for other universities, it fails to pay attention to students with difficulties caused by adverse environmental factors as it concentrates mainly on the adjustments of the study process of the students having congenital or acquired disorders.

All other policies do not specify the procedure or the criteria according to which students could apply for and are provided with certain adjustments. It is also not clear

44 Studies and Disability, Vilnius University (2020), https://www.vu.lt/en/studies/exchangestudents/living-in-lithuania/studies-and-disability (08.10.2020).

45 Disability-Friendly University, Vytautas Magnus University (2020), https://www.vdu.lt/en/ studies/why-vmu/a-disabled-friendly-university/ (08.10.2020); Open University for People with Disabilities, Vilnius University (2020), https://www.vu.lt/en/about-vu/university-life/openuniversity-for-people-with-disabilities (08.10.2020).

46 For Students with Disability, Lithuanian Sport University (2020), https://www.lsu.lt/studentams/ neigaliems-studentams/ (08.10.2020).

47 Studies and Disability, Vilnius University (2020), https://www.vu.lt/en/studies/exchangestudents/living-in-lithuania/studies-and-disability (08.10.2020).

48 Disability-Friendly University, Vytautas Magnus University (2020), https://www.vdu.lt/en/ studies/why-vmu/a-disabled-friendly-university/ (08.10.2020); Open University for People with Disabilities, Vilnius University (2020), https://www.vu.lt/en/about-vu/university-life/openuniversity-for-people-with-disabilities (08.10.2020).

49 For Students with Disabilities, Vilnius Gediminas Technical University (2020), https://www.vgtu. lt/studies/for-students-with-disabilities-/292655 (08.10.2020).

50 Procedure on the Study Individualization for the Individual Needs of Disability, Vilnius University (2019), https://www.vu.lt/site_files/Studiju_individualizavimo_pagal_individualiuosius_poreikius_ kylancius_dèl_negalios_tvarkos_aprasas.pdf (08.10.2020). 
whether and what evidence students must present when their SEN are not obvious and how the decisions are made to assign the adjustments. The lack of information, in particular creates problems for students with 'invisible' disabilities. One study reports that such students face difficulties when disclosing their disability and seeking accommodations due to the lack of understanding and questions of validity related to the lack of a physical manifestation of their disability ${ }^{51}$. Thus, the stigma associated with their disability reduces their desire to disclose it and request accommodations $\mathrm{s}^{52}$.

Only two policies state that substantiating documentation must be provided for all disabilities or medical conditions when completing the special needs form ${ }^{53}$. In all other cases students with disabilities are advised to contact a responsible person at the institution and every case is discussed and decided individually depending on student's individual needs. Although assessment of students' individual needs contributes to ensuring them equal access to the study programs and services, the lack of any established criteria or guidelines may, in some cases, hinder students to exercise their rights. The lack of information may prevent students from applying for the adjustments of their study process as they may think that they do not qualify for alternative arrangements. It is argued that not being able to identify with a particular disability category, being unaware of support, finding the access process complex or fearing stigmatisation or unequal treatment may lead to reluctance to make requests for necessary adaptations of learning environments ${ }^{54}$. The availability of different forms of information is essential to raise awareness among SEN-students of what assistive aids and support is possible and available and how to receive it.

Although a number of policies discuss only physical disability, the majority of universities have a separate section on their websites that contains information about psychological counselling. Psychological counselling offers help when students struggle emotionally, when students experience difficulties studying, anxiety, loneliness, sadness, lack of motivation, as well as in case of conflicts with others or when they are affected by personal injury, divorce, loss of family members or serious illness, eating disorders, alcohol or drug abuse and etc. ${ }^{55}$ The policies on psychological

51 L. Mullins and M. Preyde, The Lived Experience of Students with an Invisible Disability at a Canadian University, „Disability and Society 28” 2013, no. 2, p. 147-60, https://doi.org/https:// doi.org/10.1080/09687599.2012.752127.

52 Ibidem.

53 Students with Special Needs, LCC International University, https://lcc.lt/academics/studentswith-special-needs (access 04.12.2020); Studies and Disability, Vilnius University (2020), https:// www.vu.lt/en/studies/exchange-students/living-in-lithuania/studies-and-disability (08.10.2020).

54 E. Langørgen, P. Kermit, and E. Magnus, Gatekeeping in Professional Higher Education in Norway: Ambivalence among Academic Staff and Placement Supervisors towards Students with Disabilities, „International Journal of Inclusive Education” 2020, vol. 24, no. 6, p. 616-30, https:// doi.org/https://doi.org/10.1080/13603116.2018.1476599.

55 For Disabled, University of Kazimieras Simonavicius (2020), https://ksu.lt/neigaliesiems/ (08.10.2020). 
counselling encourage students in need to register for a free consultation with a psychologist. Obviously, consultations provided by a specialist may help students to understand and develop the ability to solve their personal difficulties or problems encountered during the study process. However, it stays unclear whether it is limited only to a consultation and the students are expected to solve their problems by themselves, or it actually has any affect in regard to adjustment of the study process and examination.

The analysis reveals a rather formal and narrow approach of HEIs towards students with SEN. Everyone directly supporting students with SEN needs a variety of personal and professional skills. Furthermore, incorporating inclusive teaching strategies and techniques requires even more preparation and skills. Only two policies discuss the matter of students with SEN in a broader sense ${ }^{56}$. These policies concentrate not only on the needs of the students, but also include the role of the whole community. Such policies indicate that a university's community is constantly striving to update its knowledge about SEN. They recognize that it is necessary for academic staff to participate in trainings to learn the peculiarities of students with disabilities and to provide academic staff with special material that can be effective in the teaching process ${ }^{57}$. Moreover, policies indicate where academic staff can find information about students with disabilities and even provide short tutorials that help to better understand different types of disabilities as well as ways to meet $\mathrm{SEN}^{58}$.

A number of policies do not provide any specific information for disabled students, except information on financial support. Students with 45 percent or lower capacity to work are eligible to receive financial support from the state to meet the learners' special needs ${ }^{59}$ and to have study fee partly reimbursed for students who study in non-state-funded places $^{60}$. Students can also apply for a grant to improve

56 For Students with Disability (LT), Vilnius Gediminas Technical University (2020), https://www. vgtu.lt/studentams/studentams-su-negalia/65918 (08.10.2020); Studies and Disability, Vilnius University (2020), https://www.vu.lt/en/studies/exchange-students/living-in-lithuania/studiesand-disability (08.10.2020).

57 For Students with Disabilities, Vilnius Gediminas Technical University (2020), https://www. vgtu.lt/studies/for-students-with-disabilities-/292655 (access 08.10.2020); Studies and Disability, Vilnius University (2020), https://www.vu.lt/en/studies/exchange-students/living-in-lithuania/ studies-and-disability (08.10.2020).

58 Open University for People with Disabilities, Vilnius University (2020), https://www.vu.lt/en/ about-vu/university-life/open-university-for-people-with-disabilities (08.10.2020).

5950 percent of the basic social insurance pension per month $-90,48$ Eur, starting from the $1^{\text {st }}$ of January of 2020.

60 Ruling Regarding Appliance of Measures of Financial Aid for Disabled That Are Studying in Higher Education Schools 900 \&, Government of the Republic of Lithuania (2019), https://www.etar.lt/portal/legalAct.html?documentId=41bda100cfa911 e9929af1b9eea48566 (08.10.2020). 
the accessibility of studies ${ }^{61}$. In certain cases learners can receive a monthly social grant or additional support for Erasmus+ mobility activities. In case of terminating their studies, students can be exempted from certain fees or reimbursement of a state-funded loan or part of $i^{62}$. Some universities offer exemptions from tuition and accommodation fees ${ }^{63}$. A few universities, in addition to providing advice on admission, application, study process and financial aid for the disabled students are also offering professional guidance on career planning and job search ${ }^{64}$. That helps to develop an ability to identify, analyse and independently solve problems arising during the study process and thus ensures a successful integration into the study process, and also into the labour market.

Only one of the analysed policies discusses the procedure of how the SEN are evaluated, how the decisions in regard to the adjustments of the study process and examinations are made and how academic staff is informed about the SENstudents ${ }^{65}$. However, as mentioned above, this policy does not cover students with difficulties caused by adverse environmental factors as it concentrates mainly on the adjustments of the study process of the students having congenital or acquired disorders and that can be considered as one of its main limitations. In all other cases, it stays unclear whether the decisions regarding setting different arrangements are made by the assigned person responsible for disability affairs at the university, or it is up to every lecturer to discuss that with every student individually. An important aspect is awareness of the existence of students with special needs before the course starts, as in some cases lecturers may become aware after the teaching started or even later on. The analysis demonstrates a rather fragmented approach towards students with SEN. The policies lack a systematic approach, covering all types of SEN and providing more detailed information that would cover all aspects of the study process, procedural elements, involvement of the whole community.

61 Target Payments, National Study Fund of the Republic of Lithuania (2020), https://vsf.lrv.lt/lt/ projektas/tikslines (08.10.2020).

62 Article 88, Ruling Ragrding Granting, Adminstration and Returning of State Loans and State Support Loans for Students $480 \$$, Government of the Republic of Lithuania (2009), https:// www.e-tar.lt/portal/lt/legalAct/TAR.5D93FB6D76BC/asr (08.10.2020).

63 Disability-Friendly University, Vytautas Magnus University (2020), https://www.vdu.lt/en/ studies/why-vmu/a-disabled-friendly-university/ (08.10.2020).

64 Disability Resources, Services, Mykolas Romeris University (2020), https://www.mruni.eu/ en/university/asm_spec_poreikiais/paslaugos/ (04.12.2020).; Studies and Disability, Vilnius University (2020), https://www.vu.lt/en/studies/exchange-students/living-in-lithuania/studiesand-disability (08.10.2020).

65 Procedure on the Study Individualization for the Individual Needs of Disability, Vilnius University (2019), https://www.vu.lt/site_files/Studiju_individualizavimo_pagal_individualiuosius_poreikius_ kylancius_dèl_negalios_tvarkos_aprasas.pdf (08.10.2020). 


\section{Principal Challenges and Recommendations}

This section briefly summarizes the most pivotal challenges of ensuring equality in education and makes practical recommendations for improving the inclusion of students with SEN into HEIs.

Adequate investments into practical implementation of the right to higher education for students with SEN is fundamental. However, lack of necessary funding prevents the promotion of inclusive higher education from becoming a reality. Researchers argue that insufficient funding is preconditioned by "(1) the widely held misbelief that it is too expensive to include children with disabilities (2) perceptions of low expected returns to schooling; and (3) a lack of reliable data on incidence, educational participation and achievement of children with disabilities"66. These attitudes cause the shortfall of all the essential investments into HEI staff training, acquisition of appropriate tools, hiring specialized human resources and overall adaptation of educational system to the needs of students with SEN. It is worth to mentioning that the analysis of HEI policies demonstrated two aspects of this funding problem. Firstly, although there is a goal to adapt HEI buildings and premises accessible for people with limited mobility, still much of the HEI infrastructure is still unsuited. Secondly, financial support for students with SEN is still very limited and completely inadequate. Another major drawback of effective inclusivity implementation is the preparedness of HEIs personnel, especially the academic section. Teaching staff plays a central role as in order to respond to SEN they must adapt their teaching and evaluation process. Despite believing in the idea of an inclusive education, HEI personnel do not feel prepared for teaching students with $\mathrm{SEN}^{67}$. What is more, on some occasions teaching staff is regarded as presenting the real obstacles for these students ${ }^{68}$. Lecturers often report that they lack knowledge about the peculiarities of different disabilities and special needs and do not know how they should act in different situations in order to help and

66 A.M. Sæbønes et al., Towards a Disability Inclusive Education (Background Paper for the Oslo Summit on Education for Development), „Education for Development” 2015, https://www. usaid.gov/sites/default/files/documents/1865/Oslo_Ed_Summit_DisabilityInclusive_Ed.pdf (08.10.2020).

67 J. Peebles and S. Mendaglio, Preparing Teachers for Inclusive Classrooms: Introducing the Individual Direct Experience Approach, „LEARNing Landscapes” 2014, vol. 7, no. 2, p. 245-57, https://learninglandscapes.ca/index.php/learnland/article/download/Preparing-Teachers-forInclusive-Classrooms-Introducing-the-Individual-Direct-Experience-Approach/663 (08.10.2020).

68 A.M.O. Colón, M.A. Montoro, and M.J.C. Ruiz, Toward Inclusive Higher Education in a Global Context, „Sustainability (Switzerland)” 2018, vol. 10, no. 8, https://doi.org/10.3390/su10082670. 
not to offend the students ${ }^{69}$ and also struggle to accommodate disabled students ${ }^{70}$. In fact, studies show that staff deals with SEN-students on 'trial and error' basis and rely on those students to show them how to teach them ${ }^{71}$. Even the students report the lack of awareness and insufficient knowledge about disability among academic staff $^{72}$.Moreover, SEN-students feel several barriers with regards to regular teaching approach, such as, failing to keep the pace with note taking as the teacher may talk too quickly or failing to express their ideas in an instant discussion ${ }^{73}$. This shows that HEI staff lacks a basic understanding and instructions on appropriate ways of interacting with SEN-students, not to mention a shortage of consulting specialists and helpful tools and technologies (including training on their usage), such as adapted e-learning environments, etc. As support for academic staff is considered as an indirect form of support to students with SEN as accessible HEI environment requires collaboration with and involvement of the whole HEI community - lecturers, librarians, administrative and supporting staff ${ }^{74}$, it is more than necessary to pay significantly more attention to the HEI staff training and consulting activities. However, as analysis of Lithuanian HEI policies showed, only 2 HEI policies discuss the role of whole HEI community, recognizing the necessity of staff training and providing staff with special material. Analysis also exposed the lack of guidelines and criteria for assessing students with SEN individual needs. This proves the narrow understanding of the issue presented and very apparent lack for training and providing staff with necessary information and tools.

There are several recommendations that may facilitate the inclusion of students with SEN into HEI. First and foremost is allocating adequate funding on a state level that may enable the implementation of needed changes. This is, above all, an

69 Neįmanomos Studijos Virsta Imanomomis, 15min (2016), https://www.15min.lt/naujiena/ aktualu/svietimas/neimanomos-studijos-virsta-imanomomis-233-653265 (08.10.2020).

70 S. Bunbury, Disability in Higher Education - Do Reasonable Adjustments Contribute to an Inclusive Curriculum?, „International Journal of Inclusive Education” 2020, vol. 24, no. 9, p. 96479, https://doi.org/10.1080/13603116.2018.1503347.

71 E. Gaad and M. Almotairi, Inclusion Of Student With Special Needs Within Higher Education In UAE: Issues and Challenges, „Journal of International Education Research” 2013, vol. 9, no. 4, p. 287-92, https://www.clutejournals.com/index.php/JIER/article/download/8080/8133 (08.10.2020).

72 S. Hill and A. Roger, The Experience of Disabled and Non-Disabled Students on Professional Practice Placements in the United Kingdom, „Disability and Society” 2016, vol. 31, no. 9, p. 120525, https://doi.org/10.1080/09687599.2016.1236718.

73 M. Fuller, A. Bradley, and M. Healey, Incorporating Disabled Students within an Inclusive Higher Education Environment, „Disability and Society” 2004, vol. 19, no. 5, p. 455-68, https://doi.org/ https://doi.org/10.1080/0968759042000235307.

74 European Agency for Development in Special Needs Education, Special Needs Education in Europe - Provision in Post-Primary Education, „Thematic Publication” 2017, vol. 2, https://www. european-agency.org/sites/default/files/special-needs-education-in-europe-volume-2-provisionin-post-primary-education_Thematic-EN.pdf (08.10.2020). 
indispensable condition for creating a consistent, permanent and professional system for academic and non-academic staff training. In fact, paying adequate attention to staff training is essential in order to improve quality of teaching and servicing SEN students. Matthews argues that academic staff needs "clear, accessible and comprehensive information about their responsibilities and the resources available for staff undertaking critical front-line teaching, support and referral roles" ${ }^{\prime 75}$. Such information may include, for example, clear guidelines and criteria to assess SEN students' individual needs as it was previously mentioned as a lack of Lithuanian HEI policies.

Involvement of the whole community and raising its awareness may also help in changing negative perceptions and attitudes towards students with SEN. Social connections or social adaptation is often the most serious concern as students note that the most difficult barrier they face is social isolation and lack of communication with other students and academic staff ${ }^{76}$. It is suggested that HEI should switch to the social model of disability which focuses on attitudes, thus, to change the perception of community members towards disabled students ${ }^{77}$. Bessant argues that if universities seek to ensure equal opportunities and inclusive education, their main task is a cultural change which identifies and challenges prejudice ${ }^{78}$. Matthews calls the social model of disability as the one capable of presenting new routes towards more inclusive higher education ${ }^{79}$. Although Lithuania is committed to improve the life of people with disabilities and some progress has been made since then, still changes in societal mentality regarding the attitudes and stereotypes of disabilities are needed. For example, the World Health Organization's Quality Rights assessment states that people based in 'Independent Living Homes' facilities for persons having intellectual and/or psychosocial disabilities are not at all encouraged to seek higher

75 N. Matthews, Teaching the 'invisible' Disabled Students in the Classroom: Disclosure, Inclusion and the Social Model of Disability, „Teaching in Higher Education” 2009, vol. 14, no. 3, p. 229-39, https://doi.org/https://doi.org/10.1080/13562510902898809.

76 European Agency for Development in Special Needs Education, Special Needs Education in Europe - Provision in Post-Primary Education, „Thematic Publication” 2017, vol. 2, https://www. european-agency.org/sites/default/files/special-needs-education-in-europe-volume-2-provisionin-post-primary-education_Thematic-EN.pdf (08.10.2020).

77 S. Bunbury, Disability in Higher Education - Do Reasonable Adjustments Contribute to an Inclusive Curriculum?, „International Journal of Inclusive Education” 2020, vol. 24, no. 9, p. 96479, https://doi.org/10.1080/13603116.2018.1503347.

78 J. Bessant, 'Measuring up'? Assessment and Students with Disabilities in the Modern University, „International Journal of Inclusive Education” 2012, vol. 16, no. 3, p. 265-81, https://doi.org/10.10 80/13603116.2010.489119.

79 N. Matthews, Teaching the 'invisible' Disabled Students in the Classroom: Disclosure, Inclusion and the Social Model of Disability, „Teaching in Higher Education” 2009, vol. 14, no. 3, p. 229-39, https://doi.org/https://doi.org/10.1080/13562510902898809. 
education ${ }^{80}$ and the only alternative they are sometimes informed of is the one of specialized vocational training centre ${ }^{81}$.

Among topics that are aimed at improving understanding, communication and other skills that are necessary for quality of interacting with SEN students, the introduction of innovative technologies may also help to prepare for teaching and providing support services. Another way to strengthen inclusive education is by creating advisory council units to address specialized SEN questions ${ }^{82}$. These units could not only serve as an information helpdesk for employees of HEI, but also may undertake to develop and renew institutional strategies, work plans, guidelines and monitor their implementation. Moreover, these units in consultation with relevant academic, non-academic personnel and parents may help to implement individualized approach by evaluating a student with SEN on his individual capacities and helping to develop a single adapted educational plan. These plans may become a very helpful tool for monitoring the progress of the student with SEN ${ }^{83}$. In fact, it is argued that individual educational plans help to obtain access and participation in education in the least restrictive environment ${ }^{84}$. Finally, the realization of simple means such as extra courses, extra preparation time, additional credit hours are also reasonable ways of easing the load of SEN students.

Considering both, the current climate of COVID-19 pandemic that caused the transformation of educational systems to remote learning and the rapid advancement of technologies, significantly more attention should be given to the incorporation of new technologies for students with SEN into HEI. Currently, there are many innovative tools that not only facilitate teaching and provide support, but also ease the load on SEN-students and ensure the development of their deficient skills. Many different companies throughout the world offer various instruments ${ }^{85}$

80 U. Grigaitè, Human Rights Conditions and Quality of Care in ' Independent Living Homes ' for Adults, Who Have Intellectual and/or Psychosocial Disabilities, in Vilnius: Analysis of Good Practice Examples, Systemic Challenges and Recommendations for the Future, 2017, https:// www.who.int/mental_health/policy/quality_rights/QRs_Lithuania.pdf?ua=1 (08.10.2020).

81 Ibidem.

82 G. Wise et al., Inclusive Higher Education Governance: Managing Stakeholders, Strategy, Structure and Function, „Studies in Higher Education” 2018, vol. 45, no. 2, p. 339-52, https://doi. org/https://doi.org/10.1080/03075079.2018.1525698.

83 E. Gaad and M. Almotairi, Inclusion Of Student With Special Needs Within Higher Education In UAE: Issues and Challenges, „Journal of International Education Research” 2013, vol. 9, no. 4 , p. 287-92, https://www.clutejournals.com/index.php/JIER/article/download/8080/8133 (08.10.2020).

84 J. Kurth and A.M. Mastergeorge, Individual Education Plan Goals and Services for Adolescents with Autism: Impact of Age and Educational Setting, „Journal of Special Education” 2010, vol. 44, https://doi.org/http://dx.doi.org/10.1177/0022466908329825.

85 Such as, Bookshare, Braillist, BrainControl AAC, Cboard and Global Symbol, Livox, SIMO, ReLive, etc., see more at: https://www.unicef.it/Allegati/Innovative_Assistive_Technologies_ 
that help SEN-students to gain access to learning and enjoy more independence and participation. It is argued that technologies play an important role in creating an effective and adaptable learning environment that improves various competences of SEN students ${ }^{86}$. This is the primary reason why appropriate funding must be allocated on a state level in order to grant HEI an ability to offer such technologies for students with SEN. Not only would this improve the quality of education services and accommodate SEN of those students, also it may attract more persons with SEN to enter HEI as well.

\section{Conclusions}

Significant attempts are constantly made in order to legally ensure the right to higher education for the learners with SEN on an international and national level, however, it is evident that for theory to become practice these attempts are not sufficient. International regulation is very general and declarative, whereas Lithuanian laws still have major unregulated gaps and uncertainties. Analysis of various Lithuanian HEI policies regarding students with SEN have proven the need to clarify general concepts and enact common strategies for improving SEN students' inclusion into HEI. In addition to this, more state funding should be allocated for the education of SEN students in order to ensure proper HEI staff training, gathering advisory specialists, acquiring of proper educational tools, etc. There is also a high need of developing strategies on a state level for innovative technologies implementation in the study process of students with SEN.

\section{BIBLIOGRAPHY}

Bessant J., 'Measuring up'? Assessment and Students with Disabilities in the Modern University, "International Journal of Inclusive Education" 2012, vol. 16, no. 3.

Bunbury S., Disability in Higher Education - Do Reasonable Adjustments Contribute to an Inclusive Curriculum?, "International Journal of Inclusive Education" 2020, vol. 24, no. 9.

CESCR General Comment No 13: The Right to Education (Art. 13), Office of the High Commisioner for Human Rights (1999), http://www.refworld.org/docid/4538838c22.html.

Collins A., Fara A., Rentschler R., Bringing Everyone on the Same Journey: Revisiting Inclusion in Higher Education, "Studies in Higher Education" 2018, vol. 44, no. 8.

for_inclusive_education.pdf?fbclid=IwAR09AHwm8vQ0mqEnX5-LPhY-yWLQ72KMc-5Io2uyhAlM8XjOJWtNVeBT0Uw (08.10.2020).

86 A.I. Starcic, Educational Technology for the Inclusive Classroom, „Turkish Online Journal of Educational Technology" 2010, vol. 9, no. 3, p. 26-37, https://files.eric.ed.gov/fulltext/EJ898012. pdf. 
Colón A.M.O., Montoro M.A., Ruiz M.J.C., Toward Inclusive Higher Education in a Global Context, "Sustainability (Switzerland)" 2018, vol. 10, no. 8.

Conclusions of the Council and of the Representatives of the Governments of the Member States, Meeting within the Council, on Inclusion in Diversity to Achieve a High Quality Education For All 2017/C 62/, Council of the European Union (2017), https://op.europa.eu/en/ publication-detail/-/publication/f16edd4b-fae8-11e6-8a35-01aa75ed71a1.

Convention on the Rights of Persons with Disabilities (CRPD), United Nations (2006).

Convention on the Rights of the Child, United Nations, General Assembly (1989).

Description of the Determination of Groups of the Pupils with Special Educational Needs and Procedure of the Division of the Educational Needs into the Levels, V-1265/V-6 $\$$, Minister for Education and Science and Minister for Social Security and Labour and Minister for Health (2011), https:// e-seimas.lrs.lt/portal/legalAct/lt/TAD/TAIS.404013.

Disability Resources, Services, Mykolas Romeris University (2020), https://www.mruni.eu/en/ university/asm_spec_poreikiais/paslaugos/.

Disability-Friendly University, Vytautas Magnus University (2020), https://www.vdu.lt/en/studies/ why-vmu/a-disabled-friendly-university/.

Educational Scientific and Cultural Organization, Records of the General Conference, 11th Session, Resolutions, United Nations (1960).

European Convention on Human Rights, As amended by Protocols Nos. 11 and 14, supplemented by Protocols Nos. 1, 4, 6, 7, 12, 13 and 16 \$, European Court of Human Rights. (1950).

For Disabled, University of Kazimieras Simonavicius (2020), https://ksu.lt/neigaliesiems/.

For Students with Disabilities, Vilnius Gediminas Technical University (2020), https://www.vgtu.lt/ studies/for-students-with-disabilities-/292655.

For Students with Disability, Lithuanian Sport University (2020), https://www.lsu.lt/studentams/ neigaliems-studentams/.

For Students with Disability, Vilniaus Gedimino Technikos universitetas (2020). https://www.vgtu.lt/ studentams/studentams-su-negalia/65918.

Fuller M., Bradley A., Healey M., Incorporating Disabled Students within an Inclusive Higher Education Environment, "Disability and Society" 2004, vol. 19, no. 5.

Gaad E., Almotairi M., Inclusion Of Student With Special Needs Within Higher Education In UAE: Issues and Challenges, "Journal of International Education Research" 2013, vol. 9, no. 4, https:// www.clutejournals.com/index.php/JIER/article/download/8080/8133.

General Concept of Education in Lithuania, The Ministry of Culture and Science of the Republic of Lithuania (1992), https://www.smm.lt/uploads/documents/General_concept_of_education_ in_Lithuania_1992.pdf.

Grigaite U., Human Rights Conditions and Quality of Care in ' Independent Living Homes ' for Adults, Who Have Intellectual and/or Psychosocial Disabilities, in Vilnius: Analysis of Good Practice Examples, Systemic Challenges and Recommendations for the Future, 2017. https://www.who. int/mental_health/policy/quality_rights/QRs_Lithuania.pdf?ua $=1$.

Hill S., Roger A., The Experience of Disabled and Non-Disabled Students on Professional Practice Placements in the United Kingdom, "Disability and Society" 2016, vol. 31, no. 9. 
International Covenant on Economic, Social and Cultural rights, General Assmebly United Nations (1976).

Joint Report of the Council and the Commission on the implementation of the strategic framework for European cooperation in education and training (ET 2020), 2015/C 417 \$, European Commission, and European Council (2015), http://www.refworld.org/docid/4538838c22.html.

Kurth J., Mastergeorge A.M., Individual Education Plan Goals and Services for Adolescents with Autism: Impact of Age and Educational Setting, "Journal of Special Education" 2010, vol. 44.

Langørgen E., Kermit P., Magnus E., Gatekeeping in Professional Higher Education in Norway: Ambivalence among Academic Staff and Placement Supervisors towards Students with Disabilities, "International Journal of Inclusive Education" 2020, vol. 24, no. 6.

Law onEducation of the Republic ofLithuania,I-1498\$, TheParliament of the Republic ofLithuania(1991), https://e-seimas.lrs.lt/portal/legalAct/lt/TAD/df672e20b93311e5be9bf78e07ed6470?jfwid =rivwzvpvg.

Law on Higher Education and Research, XI-242 $\$$, Republic of Lithuania (2009), https://e-seimas.lrs.lt/ portal/legalAct/lt/TAD/548a2a30ead611e59b76f36d7fa634f8?jfwid=rp9xf47k7.

Lister K., Coughlan T., Owen N., Disability' or 'Additional Study Needs'? Identifying Students' Language Preferences in Disability-Related Communications, "European Journal of Special Needs Education" 2020, no. 5.

Matthews N., Teaching the 'invisible' Disabled Students in the Classroom: Disclosure, Inclusion and the Social Model of Disability, "Teaching in Higher Education" 2009, vol. 14, no. 3.

Mullins L., Preyde M., The Lived Experience of Students with an Invisible Disability at a Canadian University, "Disability and Society" 2013, vol. 28, no. 2.

Nacionalinis Švietimo Plètotès Raportas, LR švietimo ir mokslo ministerija (2001), https://www.smm.lt/ uploads/lawacts/docs/687_f36e428baa3be1af5722f6d880e03896.pdf.

Neįmanomos Studijos Virsta İmanomomis, 15min (2016), https://www.15min.lt/naujiena/aktualu/ svietimas/neimanomos-studijos-virsta-imanomomis-233-653265.

Open University for People with Disabilities, Vilnius University (2020), https://www.vu.lt/en/about-vu/ university-life/open-university-for-people-with-disabilities.

Peebles J., Mendaglio S., Preparing Teachers for Inclusive Classrooms: Introducing the Individual Direct Experience Approach, "LEARNing Landscapes" 2014, vol. 7, no. 2, https://learninglandscapes. $\mathrm{ca} /$ index.php/learnland/article/download/Preparing-Teachers-for-Inclusive-ClassroomsIntroducing-the-Individual-Direct-Experience-Approach/663.

Procedure on the study individualization for the individual needs of disability, Vilnius University (2019), https://www.vu.lt/site_files/Studiju_individualizavimo_pagal_individualiuosius_poreikius_ kylancius_dèl_negalios_tvarkos_aprasas.pdf.

Ruling regarding appliance of measures of financial aid for disabled that are studying in higher education schools, $900 \$$, Republic of Lithuania (2019), https://www.e-tar.lt/portal/legalAct. html?documentId=41bda100cfa911e9929af1b9eea48566.

Ruling regrding granting, adminstration and returning of state loans and state support loans for students, $480 \S$, Government of the Republic of Lithuania (2009). https://www.e-tar.lt/portal/lt/ legalAct/TAR.5D93FB6D76BC/asr. 
Sæbønes A.M., Bieler R.B., Baboo N., Banham L., Singal N., Howgego C., McClain-Nhlapo C.V., Riss-Hansen T.C., Dansie G.A, Towards a Disability Inclusive Education (Background Paper for the Oslo Summit on Education for Development), "Education for Development" 2015, https://www. usaid.gov/sites/default/files/documents/1865/Oslo_Ed_Summit_DisabilityInclusive_Ed.pdf .

Simon J.A., Legal Issues in Serving Students with Disabilities in Postsecondary Education, "New Directions for Student Services" 2011, no. 134.

Special Needs Education in Europe - Provision in Post-Primary Education, European Agency for Development in Special Needs Education, “Thematic Publication” 2017, vol. 2, https://www. european-agency.org/sites/default/files/special-needs-education-in-europe-volume-2provision-in-post-primary-education_Thematic-EN.pdf.

Standard Rules on the Equalization of Opportunities for Persons with Disabilities A/RES/48/9 § (1993). https://www.independentliving.org/standardrules/StandardRules.pdf.

Starcic A.I., Educational Technology for the Inclusive Classroom, "Turkish Online Journal of Educational Technology" 2010, vol. 9, no. 3, https://files.eric.ed.gov/fulltext/EJ898012.pdf.

Students with Special Needs, LCC International University, https://lcc.lt/academics/students-with -special-needs.

Studies and Disability, Vilnius University (2020), https://www.vu.lt/en/studies/exchange-students/ living-in-lithuania/studies-and-disability.

Target Payments, National Study Fund of the Republic of Lithuania (2020), https://vsf.lrv.lt/lt/projektas/ tikslines.

The National Strategy for Education 2013-2022 (2013). https://e-seimas.lrs.lt/portal/legalAct/lt/TAD/ TAIS. 463390 .

Universal Declaration of Human Rights, United Nations (1948).

VMU Map, Vytautas Magnus university (2020), https://www.vdu.lt/en/contacts/vmu-map/.

Wise G., Dickinson C., Katan T., Gallegos M.C., Inclusive Higher Education Governance: Managing Stakeholders, Strategy, Structure and Function, "Studies in Higher Education" 2018 vol. 45, no. 2 . 